\title{
Supportive treatment for cast nephropathy in patients with multiple myeloma; a pilot study
}

\author{
Giovanni Cancarini $^{1,2^{*}(\mathbb{1})}$, Vincenzo Terlizzi ${ }^{3^{\circledR}}$, Anna Garatti $^{3^{\circledR}}$, Letizia Zeni $^{4,5}{ }^{(\mathbb{D}}$, Mattia Tonoli $^{3}$, Elena \\ Pezzini $^{3}$, Francesca Boni ${ }^{3}$, Stefano Possenti ${ }^{1}{ }^{\circledR}$, Battista Fabio Viola ${ }^{1}$, Mario Gaggiotti ${ }^{1}$ \\ ${ }^{1}$ Nephrology Operative Unit, ASST Spedali Civili Brescia, Brescia, Italy \\ ${ }^{2}$ Nephrology, Department of Medical and Surgical Specialties, Radiological Science and Public Health, University of Brescia, Brescia, Italy \\ ${ }^{3}$ Postgraduate School in Nephrology, University of Brescia, Italy \\ ${ }^{4}$ University of Campania "Luigi Vanvitelli", Naples, Italy \\ ${ }^{5}$ Fondazione Policlinico Universitario A. Gemelli IRCCS, Nephrology Operative Unit, Rome, Italy
}

\section{A R T I CLE I N F O}

Article Type:

Original

\section{Article History:}

Received: 10 October 2020

Accepted: 20 December 2020

Published online: 13 January 2021

\section{Keywords:}

Acute kidney injury, Cast nephropathy, Light chains, Mannitol, Monoclonal gammopathy of renal significance, Myeloma kidney

\begin{abstract}
A B S T RA C T
Introduction: Cast nephropathy is a prevalent cause of acute kidney injury (AKI) in patients with myeloma.

Objectives: The aim of this study is to define the outcome of a standardized supportive therapy for cast nephropathy.

Patients and Methods: Retrospective analysis of the outcome of cast nephropathy in a University hospital for a period of five years. Data analysed; serum creatinine, estimated glomerular filtration rate (eGFR; $\mathrm{mL} / \mathrm{min} / 1.73 \mathrm{~m}^{2} \mathrm{BSA}$ ) and need for dialysis. Standardized therapy with the aim of preventing/removing tubular casts; fluid administration and mannitol to increase urine flow, sodium bicarbonate to alkalize the urine and low dose steroid to reduce peritubular inflammation. Statistical analysis: Student's t-test or the Mann-Whitney test according to data distribution. A two-tailed $P$ value $<0.05$ was considered statistically significant. Survival curve was drawn according to Kaplan and Meier.

Results: Twenty-seven cases were reviewed. Upon admission, mean serum creatinine was $7.1 \pm 4.9$ $\mathrm{mg} / \mathrm{dL}$ and mean eGFR $6 \pm 4 \mathrm{~mL} / \mathrm{min} / 1.73 \mathrm{~m}^{2} \mathrm{BSA} ; 30 \%$ of patients had oligo-anuria. Diagnosis of cast nephropathy was presumptive in 23 patients, and renal biopsy proven in four. Hemodialysis was required by $10(37 \%)$ patients, two of whom continued dialysis after discharge. At discharge, serum creatinine was $3.7 \pm 2.5 \mathrm{mg} / \mathrm{dL}$ and eGFR $20 \pm 13 \mathrm{~mL} / \mathrm{min} / 1.73 \mathrm{~m}^{2} \mathrm{BSA}(P=0.002)$, and after a median of 3.4 months, the values were $2.9 \pm 2.1 \mathrm{mg} / \mathrm{dL}$ and $35 \pm 32 \mathrm{~mL} / \mathrm{min} / 1.73 \mathrm{~m}^{2} \mathrm{BSA}$, respectively. Patient survival was $60 \%$ after 24 months.

Conclusion: Administration of fluid, mannitol, sodium bicarbonate and low-dose steroid may improve the outcome of cast nephropathy. Despite the fact that the study has many limitations, its findings could be the base for prospective controlled trials on cast nephropathy and could be useful in those countries where the expensive extracorporeal treatments are not available.
\end{abstract}

Implication for health policy/practice/research/medical education:

Many papers have studied the effects of chemotherapy, dialysis, or plasma exchange on the outcome of cast nephropathy, however, none has described or standardized the supportive care. Our data suggest a standardized supportive therapy aimed to be; 1) a basis on which to design prospective controlled trials on the effects of new chemotherapy or of light chain removal method in cast nephropathy, 2) a standardized supportive therapy for those countries where the expensive extracorporeal treatments are not available.

Please cite this paper as: Cancarini G, Terlizzi V, Garatti A, Zeni L, Tonoli M, Pezzini E, Boni F, Possenti S, Fabio Viola B, Gaggiotti M. Supportive treatment for cast nephropathy in patients with multiple myeloma; a pilot study. J Nephropharmacol. 2021;10(2):e20. DOI: 10.34172/npj.2021.20.

\section{Introduction}

Multiple myeloma is a hematological malignancy characterised by an uncontrolled proliferation of plasma cells that produce a monoclonal paraprotein. Multiple myeloma causes renal involvement in $20 \%$ to $50 \%$ of affected patients, which is associated with increased mortality and morbidity $(1,2)$.

Monoclonal gammopathy of renal significance means a 
kidney damage due to paraproteins that does not meet all the criteria necessary for a diagnosis of multiple myeloma (3).

Acute kidney injury (AKI) comprises only $20 \%$ of the possible renal manifestations of multiple myeloma but has the worst prognosis in terms of patient survival and the requirement for chronic renal replacement therapy (RRT) (4). Cast nephropathy, distal tubular obstruction and tubular cell damage caused by precipitation of casts formed by light chain and Tamm-Horsfall protein, is the most frequent cause of AKI. The severity of the intratubular precipitation depends on the overload of filtered free light chains (FLC), which saturate the tubular reabsorption mechanism. Other factors are also involved in the development of cast nephropathy, including dehydration, acidic urine, high urinary sodium concentration, and use of nonsteroidal anti-inflammatory drugs (NSAIDs) (5).

The treatment of cast nephropathy includes chemotherapy for multiple myeloma, avoidance of nephrotoxic drugs, administration of fluids and diuretics to increase urinary output to at least $3 \mathrm{~L} /$ day, and, in cases of renal insufficiency, hemodialysis possibly with high cutoff (HCO) membranes. With this combination therapy, renal recovery after cast nephropathy occurs in $50 \%$ to $80 \%$ of patients $(4,6,7)$. However, the true efficacy of those membranes is not clearly defined by positive randomized controlled trials while the supportive therapy has not also been standardized as well as chemotherapy.

\section{Objectives}

The present study evaluates the renal outcome in patients treated with our standardized supportive therapy for cast nephropathy to define if this therapy could help in designing prospective randomized controlled trials on cast nephropathy and in countries where the expensive extracorporeal treatments are not available.

\section{Patients and Methods}

\section{Study design}

This is retrospective study that reports the course and outcome of all patients admitted to the Nephrology Operative Unit, ASST Spedali Civili Brescia, from January 1, 2013 through December 31, 2018, with a diagnosis of AKI due to cast nephropathy.

Presumptive cast nephropathy was diagnosed on the basis of clinical and laboratory data according to previous papers $(4,8-11) ; 1)$ onset of AKI with no suggestion for other renal disease or pharmacological effect, 2) high serum concentration of FLC, 3) peak in the gamma region on urine electrophoresis, identified as light chains by urine immunofixation.

\section{Laboratory tests}

Renal function was estimated using the CKD-EPI (Chronic Kidney Disease Epidemiology Collaboration) equation. Data on renal function at the time of admission, its peak and its value at discharge and one month later were recorded, as well as the therapies given, the need for hemodialysis, and technical data of dialysis sessions.

\section{Ethical issues}

The study was performed in accordance with the Declaration of Helsinki and all the patients gave their consent for the therapy proposed. The study is retrospective and non-interventional (i.e., analysis of the current standard therapy), since informed consents were obtained at the time of patients' admission.

\section{Statistical analysis}

All data retrieved from the clinical charts and electronic records were anonymised and recorded in an Excel file (Microsoft Corporation, Redmond, WA, USA). The results are reported as the mean and standard deviation or median and interquartile range (IQR) based on their distribution. The results of the different characteristics were compared using Student's t-test or the MannWhitney $U$ test according to their distribution. A twotailed $P$ value of less than 0.05 was considered statistically significant.

Results

\section{Clinical data at presentation}

Twenty-seven patients with AKI due to cast nephropathy were admitted to our nephrology operative unit in a 5 -year period. The baseline characteristics of the study population are shown in Table 1 . Of the 27 patients, 7 (26\%) had pre-existing chronic kidney disease defined as an estimated glomerular filtration rate (eGFR) $<60$ $\mathrm{mL} / \mathrm{min} / \mathrm{m}^{2}$ body surface area (BSA). Mean baseline serum creatinine $(\mathrm{sCr})$ before admission was $1.2 \pm 0.7$ $\mathrm{mg} / \mathrm{dL}$ and mean patient age was $73 \pm 11$ years. The main comorbidities were as follows; hypertension (19/27, $70 \%)$, peripheral artery disease $(7 / 27,26 \%)$, and type 2 diabetes mellitus $(3 / 27,11 \%)$. Diagnosis of the underlying haematological disease was monoclonal gammopathy of undetermined significance in five patients and multiple myeloma in 12 patients, with a mean follow-up of 20.9 months (IQR 6.2-93.7). The remaining 10 patients were not diagnosed with monoclonal gammopathy.

At the time of admission to the hospital, the mean serum creatinine concentration was $7.1 \pm 4.9 \mathrm{mg} / \mathrm{dL}$ (eGFR $6 \pm 4$ $\mathrm{mL} / \mathrm{min} / 1.73 \mathrm{~m}^{2} \mathrm{BSA}$ ); $30 \%$ of patients had oligo-anuria. Admissions to the hospital occurred between the months of June and September for 14 patients and dehydration and/or use of NSAIDs were identified as precipitating factors for cast nephropathy in $22 \%$ of the cases.

Diagnosis of cast nephropathy was made on the basis of the three criteria listed in the above section and was confirmed by renal biopsy in 4/27 (15\%) of the patients.

The laboratory profile at admission is shown in Table 1. Two patients exhibited mild hypercalcemia (calcium $10.9 \mathrm{mg} / \mathrm{dL}$ and $11.1 \mathrm{mg} / \mathrm{dL}$, and 24-hour proteinuria 
Table 1. Main characteristics of the population studied

\begin{tabular}{|c|c|}
\hline Number of patients & 27 \\
\hline Male sex & $13(48 \%)$ \\
\hline Age (years) & $73 \pm 11$ \\
\hline $\begin{array}{l}\text { Previous known monoclonal } \\
\text { gammopathy of undetermined } \\
\text { significance }\end{array}$ & $5(19 \%)$ \\
\hline Previous diagnosis of multiple myeloma & 12 (44\%) \\
\hline Hypertension & $19(70 \%)$ \\
\hline Peripheral vascular disease & $7(26 \%)$ \\
\hline Diabetes mellitus & $3(11 \%)$ \\
\hline Baseline creatinine $(\mathrm{mg} / \mathrm{dL})$ & $1.2 \pm 0.7$ \\
\hline $\begin{array}{l}\text { Baseline eGFR (mL/min/1.73 } \mathrm{m}^{2} \mathrm{BSA} \text { ) } \\
\text { (CKD-EPI formula) }\end{array}$ & $60 \pm 27$ \\
\hline Serum creatinine at admission $(\mathrm{mg} / \mathrm{dL})$ & $7.1 \pm 4.9$ \\
\hline Peak of serum creatinine $(\mathrm{mg} / \mathrm{dL})$ & $9.2 \pm 4.0$ \\
\hline $\begin{array}{l}\text { Lower value of eGFR ( } \mathrm{mL} / \mathrm{min} / 1.73 \mathrm{~m}^{2} \\
\text { BSA) CKD-EPI formula) }\end{array}$ & $6 \pm 4$ \\
\hline Haemoglobin (g/dL) & $9.1 \pm 1.3$ \\
\hline $\begin{array}{l}\text { White blood cells }\left(10^{\wedge} 3 / \mu \mathrm{L}\right) \text { at } \\
\text { admission }\end{array}$ & $6.3 \pm 2.2$ \\
\hline Platelets $\left(10^{\wedge} 3 / \mu \mathrm{L}\right)$ at admission & $148 \pm 66$ \\
\hline Serum calcium (mg/dL) & $8.8 \pm 1.2$ \\
\hline Urine proteins (g/day) & $2.5 \pm 1.7$ \\
\hline Free Light Chains (mg/L) & 2030 (IQR 1103-5018) \\
\hline $\mathrm{FLC} \mathrm{k} \mathrm{(mg/L)}$ & 4075 (IQR 1648-6423) \\
\hline $\mathrm{FLC} \lambda(\mathrm{mg} / \mathrm{L})$ & 1300 (IQR 805-2150) \\
\hline $\operatorname{lgG}(\mathrm{mg} / \mathrm{dL})$ & 615 (IQR 296-1585) \\
\hline $\operatorname{lgM}(\mathrm{mg} / \mathrm{dL})$ & 18 (IQR 9-22) \\
\hline $\operatorname{lgA}(\mathrm{mg} / \mathrm{dL})$ & 28 (IQR 11-55) \\
\hline
\end{tabular}

$2.5 \pm 1.7 \mathrm{~g} / \mathrm{d}$ ). Transfusion of red cells and/or platelets was necessary in $18 / 27(67 \%)$ of patients.

The subclasses of para-proteins found were: IgGk in 7 patients, micromolecular myeloma $\kappa$ in 6 , micromolecular myeloma $\lambda$ in $7, \operatorname{IgG} \lambda$ in $3, \operatorname{Ig} A \lambda$ in 3 , and $\operatorname{Ig} A \kappa$ in 1 case. Median serum FLC was $2030 \mathrm{mg} / \mathrm{L}$ (IQR 1103-5018); in light-chain $\kappa$ myeloma, the median serum concentration of $\kappa$ chains was $4075 \mathrm{mg} / \mathrm{L}$ (IQR 1648-6423), whereas in light-chain $\lambda$ myeloma, the median $\lambda$ concentration in the serum was $1300 \mathrm{mg} / \mathrm{L}$ (IQR 805-2150).

Supportive renal therapy for cast nephropathy was a combination of oral steroid (i.e., prednisone 25 $\mathrm{mg} / \mathrm{d}$ ), urinary alkalisation (goal: $\mathrm{pH} 7$ ) with sodium bicarbonate given orally or intravenously $(1 / 6 \mathrm{M})$, free access to water, and 50-100 $\mathrm{ml}$ of mannitol $18 \mathrm{~g} / \mathrm{dL}$ administered intravenously two to three times daily. Steroids were administered in 96\% (26/27) of subjects, sodium bicarbonate in $93 \%(25 / 27)$, and mannitol in $85 \%$ (23/27).

Chemotherapy schemes were established by the haematologist consultant according to the available drugs, myeloma stage, previous treatment strategies, renal function, and single patient comorbidities. Steroids were used in $89 \%$ of cases, bortezomib in $52 \%$, thalidomide and its derivatives in $22 \%$, melphalan in $11 \%$, cyclophosphamide in 7\%, and carfilzomib in $4 \%$.

Ten (37\%) patients required dialysis, and in them the mean duration of RRT was 25 days (IQR 7-49) corresponding to 14 sessions (IQR 3-38). The characteristics of the 10 patients requiring RRT and the types of dialysers are shown in Table 2 . In 8 of the 10 patients $(80 \%)$ on RTT, dialysis was discontinued when renal function improved significantly, and urinary output was restored. Two patients continued RTT after discharge.

Mean hospitalisation duration was $29 \pm 18$ days (median 24; IQR 15-40). At the time of hospital discharge, renal function was significantly improved, with mean serum creatinine $3.7 \pm 2.5 \mathrm{mg} / \mathrm{dL}$ corresponding to eGFR $20 \pm 13$ $\mathrm{mL} / \mathrm{min} / 1.73 \mathrm{~m}^{2}$ BSA $(P=0.002)$. One month after the diagnosis of cast nephropathy, serum creatinine was $2.9 \pm 1.5 \mathrm{mg} / \mathrm{dL}$ with eGFR $24 \pm 14 \mathrm{~mL} / \mathrm{min} / 1.73 \mathrm{~m}^{2}$ BSA. One patient, discharged on RRT, stopped dialysis after 82 sessions over 193 days due to renal functional recovery. The other one continued on dialysis. At the end of the follow-up, after a median of 3.4 months (IQR 1.2-5.9), the serum creatinine was $2.9 \pm 2.1 \mathrm{mg} / \mathrm{dL}$ and eGFR was $35 \pm 32 \mathrm{~mL} / \mathrm{min} / 1.73 \mathrm{~m}^{2}$ BSA.

Comparison of the eGFR values between patients who required dialysis and those who did not is shown in Table 3. Patients who did not require dialysis had higher eGFR values over the long-term.

A total of 8 patients (30\%) died during the follow-up. Figure 1 shows the cumulative survival of the patients.

\section{Discussion}

This retrospective observational study describes 27 patients with clinically diagnosed cast nephropathy. Cast nephropathy, with a prevalence of $32.0 \%-47.5 \%$ (12), is the most common cause of AKI in the course of multiple myeloma and is considered a sufficient diagnostic criterion for multiple myeloma according to the "International Myeloma Working Group" (13).

Only 4 of 27 patients (15\%) had a biopsy-confirmed diagnosis of cast nephropathy. Thrombocytopenia, prolonged bleeding time, or seriously compromised general conditions excluded renal biopsy in most of the patients. Therefore, most patients were diagnosed on the basis of the criteria suggested by published papers (8-11).

Upon admission, $26 \%$ of the patients had values of eGFR typical of an elderly population. Furthermore, before hospitalisation, $22 \%$ of patients experienced the two main risk factors for cast nephropathy; dehydration, NSAID use, or both. Other known triggers for AKI, such as hypercalcemia, infectious events, and bisphosphonates, were not present in the study population. At the time of admission, all patients had AKI (30\% with oliguria) with a mean serum creatinine at baseline of $7.1 \pm 4.9 \mathrm{mg} / \mathrm{dL}$, which peaked at $9.2 \pm 4.0 \mathrm{mg} / \mathrm{dL}$ during hospitalisation.

Generally, cast nephropathy is treated with chemotherapy against multiple myeloma to reduce the production of 
Table 2. Main characteristics of those patients who needed dialysis

\begin{tabular}{|c|c|c|c|c|c|c|c|c|c|c|c|c|c|c|c|c|c|c|c|c|}
\hline $\mathrm{n}$ & Sex & Age & $\begin{array}{l}\text { Previous } \\
\text { diagnosis of } \\
\text { MGUS }\end{array}$ & $\begin{array}{l}\text { Previous } \\
\text { diagnosis of } \\
\text { Myeloma }\end{array}$ & $\begin{array}{c}\text { Type og } \\
\text { monoclonal } \\
\text { protein }\end{array}$ & Stage & $\begin{array}{c}\text { Time between } \\
\text { myeloma } \\
\text { diagnosis and } \\
\text { CN (months) }\end{array}$ & $\begin{array}{l}\text { oligo } \\
\text { anuria }\end{array}$ & $\begin{array}{l}\text { Days } \\
\text { on HD }\end{array}$ & Dialyzer & $\begin{array}{c}\mathrm{FLC} \mathrm{k} \\
(\mathrm{mg} / \mathrm{L})\end{array}$ & $\begin{array}{c}\mathrm{FLC} \lambda \\
(\mathrm{mg} / \mathrm{L})\end{array}$ & $\mathrm{FLC} \mathrm{k} / \lambda$ & Mannitol & Steroid & $\mathrm{NaHCO}_{3}$ & $\begin{array}{c}\text { Haematologic } \\
\text { therapy }\end{array}$ & $\begin{array}{c}\text { HD } \\
\text { withdrawal }\end{array}$ & Death & $\begin{array}{l}\text { Follow } \\
\text { up } \\
\text { (months) }\end{array}$ \\
\hline 2 & Male & 67 & No & Yes & IgGk & $1 \mathrm{~A}$ & 200 & Yes & 13 & $\begin{array}{l}\text { FX } 80+F X \\
\text { cordiax } 100\end{array}$ & 3960 & 22 & 176.80 & Yes & Yes & Yes & $\begin{array}{c}\text { Bortezomib. } \\
\text { dexamethasone }\end{array}$ & Yes & No & 42.2 \\
\hline 8 & Male & 75 & No & Yes & IgAk & $3 \mathrm{~A}$ & 2 & Yes & 27 & Fx80 & 9830 & 11 & 862.00 & Yes & Yes & Yes & $\begin{array}{c}\text { Bortezomib + } \\
\text { dexamethasone }\end{array}$ & Yes & No & 4.1 \\
\hline 12 & Female & 77 & No & Yes & Micromol. $\lambda$ & $2 \mathrm{~A}$ & 74 & Yes & 245 & $\begin{array}{c}\text { Revaclear } \\
400\end{array}$ & 2 & 1300 & 0.01 & Yes & Yes & Yes & $\begin{array}{l}\text { Pomalidomide. } \\
\text { steroids }\end{array}$ & No & Yes & 8.4 \\
\hline 18 & Female & 74 & No & Yes & Micromol. k & $3 \mathrm{~A}$ & 11 & Yes & 41 & $\begin{array}{c}\text { Revaclear } \\
400\end{array}$ & 1120 & 22 & 52.10 & Yes & Yes & Yes & $\begin{array}{c}\text { Lenalidomide } \\
+ \text { Steroids ( } 2 \\
\text { cycles }\end{array}$ & Yes & No & 2.5 \\
\hline 19 & Female & 56 & No & No & Micromol. $\lambda$ & NA & 0 & Yes & 52 & $\begin{array}{c}\text { Theranova } \\
500\end{array}$ & 1 & 1050 & 0.02 & No & Yes & Yes & $\begin{array}{c}\text { Bortezomib + } \\
\text { dexamethasone }\end{array}$ & Yes & No & 1.9 \\
\hline 20 & Female & 81 & No & No & $\lg G \lambda$ & NA & 0 & No & 193 & $\begin{array}{c}\text { Revaclear } \\
400\end{array}$ & 41 & 1480 & 0.02 & No & Yes & No & $\begin{array}{c}\text { Bortezomib + } \\
\text { dexamethasone }\end{array}$ & No & No & 5.4 \\
\hline 21 & Male & 88 & No & Yes & $\lg G \lambda$ & $3 \mathrm{~A}$ & 25 & Yes & 5 & Fx80 & 9 & 2550 & 0.01 & Yes & Yes & Yes & Prednisone & Yes & No & 0.6 \\
\hline 23 & Male & 74 & No & No & Micromol. $\lambda$ & NA & 0 & Yes & 23 & $\begin{array}{c}\text { Fx80 } \\
+ \text { Theranova } \\
500\end{array}$ & 13 & 1110 & 0.01 & Yes & Yes & Yes & $\begin{array}{c}\text { Bortezomib e } \\
\text { dexamethasone }\end{array}$ & Yes & No & 4.5 \\
\hline 27 & Female & 61 & No & No & Micromol. k & NA & 0 & No & 1 & $\begin{array}{c}\text { Theranova } \\
500\end{array}$ & 4840 & 17 & 286.40 & Yes & Yes & Yes & $\begin{array}{c}\text { Bortezomib + } \\
\text { dexamethasone }\end{array}$ & Yes & No & 3.4 \\
\hline
\end{tabular}


Table 2. Continued ${ }^{a}$

\begin{tabular}{|c|c|c|c|c|c|c|c|c|c|}
\hline & $\begin{array}{l}\text { Baseline } \mathrm{sCr} \\
(\mathrm{mg} / \mathrm{dL})\end{array}$ & $\begin{array}{c}\text { Baseline eGFR } \\
\left(\mathrm{mL} / \mathrm{min} / 1.73 \mathrm{~m}^{2} \mathrm{BSA}\right)\end{array}$ & $\begin{array}{l}\text { At admission sCr } \\
\qquad(\mathrm{mg} / \mathrm{dL})\end{array}$ & $\begin{array}{c}\text { Peak sCr (mg/ } \\
\text { dL) }\end{array}$ & $\begin{array}{l}\text { Minimum eGFR (mL/ } \\
\left.\min / 1.73 \mathrm{~m}^{2} \mathrm{BSA}\right)\end{array}$ & $\begin{array}{l}\text { At discharge } \mathrm{s} C r(\mathrm{mg} / \\
\mathrm{dL})\end{array}$ & $\begin{array}{l}\text { At discharge eGFR (mL/ } \\
\left.\mathrm{min} / 1.73 \mathrm{~m}^{2} \mathrm{BSA}\right)\end{array}$ & $\begin{array}{l}\text { Last sCreat } \\
\text { (mg/dL) }\end{array}$ & $\begin{array}{c}\text { Last eGFR } \\
\left(\mathrm{mL} / \mathrm{min} / 1.73 \mathrm{~m}^{2} \mathrm{BSA}\right)\end{array}$ \\
\hline & 0.8 & 92 & 16.0 & 17.9 & 2 & 4.1 & 14 & 5 & 5 \\
\hline & 1.7 & 39 & 5.9 & 11.3 & 4 & 4.1 & 13 & 7.5 & 6 \\
\hline & 0.7 & 84 & 1.6 & 11.1 & 3 & 4.28 & 9 & 3.17 & 13 \\
\hline & 1.3 & 40 & 13.9 & 13.9 & 2 & 2.3 & 20 & 2.3 & 20 \\
\hline & 0.7 & 97 & 14.1 & 14.1 & 3 & $\mathrm{HD}$ & $\mathrm{HD}$ & 3.4 & 14 \\
\hline & 0.7 & 81 & 13.0 & 13.0 & 2 & $\mathrm{HD}$ & $\mathrm{HD}$ & $\mathrm{HD}$ & $\mathrm{HD}$ \\
\hline & 1.0 & 67 & 11.4 & 11.4 & 3 & 4 & 13 & 4 & 13 \\
\hline & 1.4 & 49 & 7.0 & 7.0 & 7 & 1.8 & 37 & 1.3 & 54 \\
\hline & 1.0 & 74 & 1.6 & 12.5 & 3 & 2.11 & 30 & 2 & 32 \\
\hline & 1.2 & 49 & 14.7 & 14.7 & 2 & 4.1 & 11 & 1.3 & 44 \\
\hline Mean & $1.1 \pm 0.3$ & $67 \pm 22$ & $9.9 \pm 5.5$ & $12.7 \pm 2.9$ & $3 \pm 2$ & $3.3 \pm 1.1$ & $18 \pm 10$ & $3.3 \pm 2.0$ & $22 \pm 17$ \\
\hline
\end{tabular}

Abbreviations: CN, cast nephropathy; FLC, free light chains; HD, haemodialysis; MGUS, monoclonal gammopathy of undetermined significance.

${ }^{a}$ Columns belong to the right of Table 2 and each row is a continuation of the first part of Table 2 . 
Table 3. Changes in eGFR $\left(\mathrm{mL} / \mathrm{min} / 1.73 \mathrm{~m}^{2} \mathrm{BSA}\right)$ in patients who did or did not require dialysis

\begin{tabular}{|c|c|c|c|}
\hline & Patients who required dialysis & Patients who did not require dialysis & $P$ value \\
\hline Number of patients & 10 & 17 & \\
\hline Baseline eGFR & $67.2 \pm 21.6$ & $55.8 \pm 29.3$ & 0.30 \\
\hline Lower value of eGFR & $3.1 \pm 1.5$ & $7.5 \pm 3.8$ & $<0.001$ \\
\hline eGFR at discharge & $18.4 \pm 10.0$ & $20.3 \pm 14.2$ & 0.73 \\
\hline eGFR at 1 month after discharge & $21.5 \pm 10.7$ & $25.6 \pm 16.0$ & 0.58 \\
\hline eGFR at last check & $24.0 \pm 19.5$ & $40.7 \pm 37.1$ & 0.28 \\
\hline
\end{tabular}

light chains, in combination with support strategies aimed toward eliminating FLC casts that cause intratubular obstruction and preventing further FLC precipitation. Clearly, chemotherapy is the sine qua non condition for survival of patients with multiple myeloma, but the drug selection and dose strongly depend on the patient's renal function. Therefore, partial, or total recovery of AKI is crucial toward optimising the management of multiple myeloma.

First-line chemotherapy for cast nephropathy is bortezomib in combination with high doses of steroids $(14,15)$. Other options include cyclophosphamide, thalidomide, lenalidomide, and carfilzomib (16). For eligible patients, stem cell transplantation is another possibility (17).

Currently accepted support therapy for cast nephropathy includes; 1) administering fluids to increase urinary output to $>3 \mathrm{~L} /$ day (with caution in case of heart failure or oliguric AKI); 2) increasing urine $\mathrm{pH}$; and 3) withdrawing potentially nephrotoxic drugs (e.g., NSAIDs, angiotensinconverting enzyme-inhibitors and angiotensin receptor blockers). The rationale behind increasing urinary flow is to reduce the FLC concentration to protect against cast formation and to potentially flush away any casts already present.

Patients with AKI are often oliguric, requiring diuretics to increase urinary flow. When choosing the type of diuretic, one has to consider that the increased sodium concentration in the urine favours tubular cast formation, probably by enhancing the production

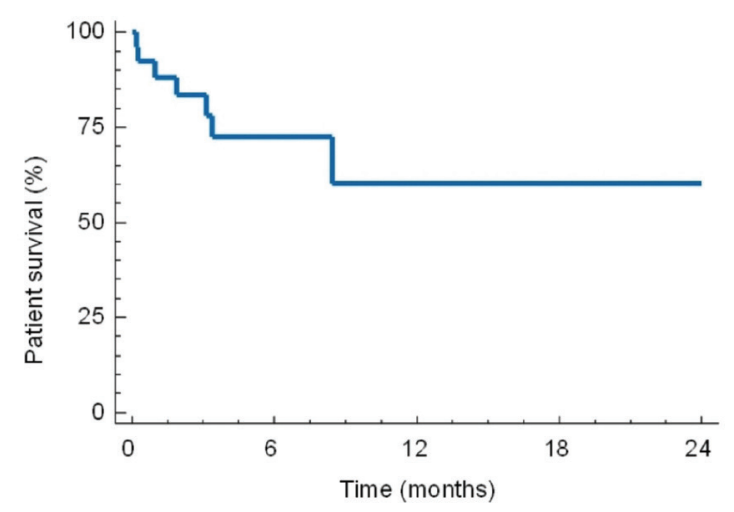

Figure 1. Cumulative patient survival. of Tamm-Horsfall glycoprotein $(18,19)$. As a result, furosemide and other diuretics that act by reducing sodium reabsorption should be avoided and osmotic diuretics preferentially administered. Mannitol acts in the proximal and distal tubules and produces water diuresis with an important washout effect that could flush out casts and cellular debris (20). In addition to its diuretic effect, mannitol acts as to scavenge hydroxyls and other free radicals, minimizing cell injury by its antioxidant effect (20), and improves renal blood flow by enhancing the local production of prostaglandins and reducing renin levels (21). The beneficial effects of mannitol have been called into question, however, as it may also cause volume depletion and increase medullary consumption of oxygen by increasing the distal delivery of solutes (22). Bragadottir et al (21), however, demonstrated that mannitol induces renal vasodilation and increases renal blood flow, thereby maintaining the filtration fraction and renal oxygenation. In our patients, $18 \mathrm{~g} / \mathrm{dL}$ mannitol was infused intravenously, starting with $50 \mathrm{ml}$ twice daily and then progressively increasing according to the clinical response, up to $100 \mathrm{ml}$ three times daily. Fluid input was adjusted to avoid dehydration or fluid overload. Neither hyperosmolar syndrome nor symptoms of the central nervous system, hypernatremia, and hyponatremia were observed in our patients.

An acidic $\mathrm{pH}$ of the urine favours FLC precipitation (23); thus, the urine $\mathrm{pH}$ should be increased to a neutral or basic value, with avoidance of alkalosis, which could lead to calcium phosphate deposition in kidneys, vessels, and elsewhere. We targeted a urine $\mathrm{pH}$ of 7 and measured the serum bicarbonate concentration every day.

In renal biopsies of 70 patients with cast nephropathy, Ecotière et al (24) reported moderate or severe tubular atrophy and moderate/severe interstitial fibrosis in $60 \%$ of cases, tubular necrosis in $46 \%$, tubulorrhexis in $31 \%$, interstitial granuloma in $21 \%$, and moderate or severe interstitial inflammation in $31 \%$. The extent of the interstitial fibrosis and tubular atrophy was similar, and their severity was associated with a poor renal outcome (24). A low-dose of prednisone (25 mg/d orally) was given, to those patients not already taking steroids for treatment of multiple myeloma, in order to reduce interstitial inflammation, which could cause irreversible interstitial fibrosis and tubular atrophy. 
As many as $37 \%$ of our patients required RRT to control the complications of AKI. Dialysis was performed using one of the following filters: FX 80 (Fresenius Medical Care), Revaclear 400 (Baxter, Deerfield, IL, USA) and Theranova 500 (Baxter, Deerfield, IL, USA). The duration of RRT was extremely variable, with a mean of 25 days and 14 dialysis sessions. Noteworthy, in one case was dialysis stopped long after discharge (193 days, 82 haemodialysis sessions) and one patient is still on dialysis.

Current clinical practice in the treatment of cast nephropathy includes dialysis in the event of severe complications of renal failure, such as oliguria, hyperkalaemia, or fluid overload; furthermore, dialysis has also been suggested as a method to remove light chains from blood to reduce the risk of cast nephropathy. Hutchison et al (25) demonstrated the usefulness of dialysis with $\mathrm{HCO}$ membranes, together with effective chemotherapy, for reducing the high concentrations of serum light chains. It is important to note that light chain removal by dialysis did not provide a clear advantage for reversing renal damage in two randomised controlled trials: the MYRE trial (26) and the EuLITE trial (7). In the MYRE trial, the patients were divided into two groups: group 1 was treated with standard filters and group 2 with HCO filters. The primary outcome, independence from haemodialysis at 3 months, did not differ between the two groups (33.3\% versus $41.3 \%$ ), but the study was likely too undersized to identify early clinically important differences (26). Additionally in the EuLITE trial, no significant difference was found in dialysis independence at 3 months in patients on dialysis with HCO filters compared to those on dialysis with standard filters $(56 \%$ versus $51 \%, P=0.81$ ) (7).

As stated by the consensus of the International Myeloma Working Group, renal response is based on eGFR changes. Renal response is classified as complete if baseline eGFR improves from $<50$ to $\geq 60 \mathrm{~mL} / \mathrm{min} / 1.73 \mathrm{~m}^{2} \mathrm{BSA}$, partial if it begins $<15$ and reaches $30-59 \mathrm{~mL} / \mathrm{min} / 1.73 \mathrm{~m}^{2} \mathrm{BSA}$, or minor if eGFR changes from $<15$ to $15-29 \mathrm{~mL} / \mathrm{min} / 1.73$ $\mathrm{m}^{2}$ BSA or from $15-29$ to $30-59 \mathrm{~mL} / \mathrm{min} / 1.73 \mathrm{~m}^{2}$ BSA (27). In a Greek study, $37 \%$ of (31/83) multiple myeloma patients with eGFR $<30 \mathrm{~mL} / \mathrm{min} / 1.73 \mathrm{~m}^{2}$ BSA required RRT. Renal function improved in $72 \%$, but only $48 \%$ remained dialysis-independent (28). In a French report on 70 patients with cast nephropathy, only $32(46 \%)$ had an $\mathrm{eGFR} \geq 30 \mathrm{~mL} / \mathrm{min} / 1.73 \mathrm{~m}^{2} \mathrm{BSA}$ and/or were independent of dialysis after three months; this percentage was reduced to $38 \%$ among the 31 patients who had to start haemodialysis (20).

Plasmapheresis is another suggested method for removing light chains from the blood; however, no randomised controlled trials have demonstrated any benefit over medical therapy (29).

\section{Conclusion}

The high prevalence of a renal response suggests that the therapy given (i.e., mannitol, sodium bicarbonate, fluids, and steroids associated with chemotherapy) should be considered when caring for this type of patients and could be a base for define a standardized supportive therapy when designing studies to evaluate the effects of chemotherapy or dialysis in cast nephropathy. Moreover, it is a suggestion for a standardized supportive therapy in those countries where the expensive extracorporeal treatments are not available.

\section{Limitations of the study}

The present work has some limitations, such as the retrospective nature, single-centre study, and a clinical diagnosis of cast nephropathy supported only in few cases by renal biopsy. Some of these points are shared by many papers published on this topic and, mainly, the retrospective nature and the difficulty of performing renal biopsy due to the bleeding risk resulting from the low number of platelets (25). The possibility that other types of AKI caused the decrease in renal function cannot be excluded, as noted in previously published papers.

\section{Authors' contribution}

GC, MG and BFV have planned and controlled the therapy. GC, VT, and MG conducted the research. VT, AG, LZ MT, $\mathrm{EP}, \mathrm{FB}, \mathrm{SP}$ and BFV examined the clinical records and collected the data. GC, VT, and SP analysed the data. GC and VT wrote the manuscript. All the Authors checked and approved the final version of the manuscript.

\section{Conflicts of interest}

The authors declare that they have no competing interests.

\section{Ethical considerations}

Ethical issues (including plagiarism, data fabrication, double publication) have been completely observed by the authors.

\section{Funding/Support}

Funds of the University of Brescia supported the study.

\section{References}

1. Dimopoulos MA, Sonneveld P, Leung N, Merlini G, Ludwig $\mathrm{H}$, Kastritis E, et al. International Myeloma Working Group recommendations for the diagnosis and management of myeloma-related renal impairment. J Clin Onc. 2016;34:1544-57. doi: 10.1200/JCO.2015.65.0044.

2. Lahoti A, Glass WF II. Multiple myeloma and the kidney. J Onco Nephrol 2017;1:95-102. doi: 10.5301/jo-n.5000017.

3. Bridoux F, Leung N, Hutchison CA, Touchard G, Sethi S, Fermand JP, et al. Diagnosis of monoclonal gammopathy of renal significance. Kidney Int. 2015;87:698-711. doi: 10.1038/ki.2014.408.

4. Sathick IJ, Drosou ME, Leung N. Myeloma light chain cast nephropathy, a review. J Nephrol. 2019;32:189-98. doi: 10.1007/s40620-018-0492-4.

5. Sethi S, Rajkumar SV, D'Agati VD. The complexity and 
heterogeneity of monoclonal immunoglobulin-associated renal diseases. J Am Soc Nephrol. 2018;29:1810-23. doi: 10.1681/ASN.2017121319.

6. Curti A, Schwarz A, Trachsler J, Tomonaga Y, Ambuhl PM. Therapeutic efficacy and cost effectiveness of high cut-off dialyzers compared to conventional dialysis in patients with cast nephropathy. PLoS One. 2016;11:e0159942. doi: 10.1371/journal.pone.0159942.

7. Hutchison CA, Cockwell P, Moroz V, Bradwell AR, Fifer L, Gillmore JD, et al. High cutoff versus high-flux haemodialysis for myeloma cast nephropathy in patients receiving bortezomib-based chemotherapy (EuLITE): a phase 2 randomised controlled trial. Lancet Haematol. 2019;6:e217-22. doi: 10.1016/S2352-3026(19)30014-6.

8. Hutchison CA, Batuman V, Behrens J, Bridoux F, Sirac C, Dispenzieri A, et al. The pathogenesis and diagnosis of acute kidney injury in multiple myeloma. Nat Rev Nephrol. 2011;8:43-51. doi: 10.1038/nrneph.2011.168.

9. Hudier L, Decaux O, Haddj-Elmrabet A, Lino M, Mandart L, Siohan P, et al. Intensive haemodialysis using PMMA dialyser does not increase renal response rate in multiple myeloma patients with acute kidney injury. Clin Kidney J. 2018;11:230-5. doi: 10.1093/ckj/sfx079.

10. Appel GB, Leung N, Rajkumar SV. Clinical features, evaluation, and diagnosis of kidney disease in multiple myeloma and other monoclonal gammopaties. In: https:// www.uptodate.com. Accessed 12 June 2019.

11. Finkel KW, Cohen EP, Shirali A, Abudayyeh A. Paraproteinrelated kidney disease: evaluation and treatment of myeloma cast nephropathy. Clin J Am Soc Nephrol. 2016;11:2273-9. doi: 10.2215/CJN.01640216.

12. Herrera GA, Joseph L, Gu X, Hough A, Barlogie B. Renal pathologic spectrum in an autopsy series of patients with plasma cell dyscrasia. Arch Pathol Lab Med. 2004;128:875-9. doi: 10.1043/1543-2165(2004)128<875:RPSIAA>2.0.CO;2.

13. Rajkumar SV, Dimopoulos MA, Palumbo A, Blade J, Merlini G, Mateos MV, et al. International Myeloma Working Group updated criteria for the diagnosis of multiple myeloma. Lancet Oncol. 2014;15:e538-48. doi: 10.1016/S14702045(14)70442-5.

14. Bayraktar UD, Warsch S, Pereira D. High-dose glucocorticoids improve renal failure reversibility in patients with newly diagnosed multiple myeloma. Am J Hematol. 2011;86:224-7. doi: 10.1002/ajh.21922.

15. Sonneveld P, Schmidt-Wolf IG, van der Holt B, El Jarari L, Bertsch U, Salwender H, et al. Bortezomib induction and maintenance treatment in patients with newly diagnosed multiple myeloma: results of the randomized phase III HOVON-65/ GMMG-HD4 trial. J Clin Oncol. 2012;30:2946-55. doi: 10.1200/JCO.2011.39.6820.

16. Mikhael J, Ismaila N, Cheung MC, Costello C, Dhodapkar MV, Kumar S, et al. Treatment of Multiple Myeloma: ASCO and CCO Joint Clinical Practice Guideline. J Clin Oncol. 2019;37:1228-63. doi: 10.1200/JCO.18.02096.

17. El Fakih R, Fox P, Popat U, El Fakih R, Fox P, Popat U, et al. Autologous hematopoietic stem cell transplantation in dialysis-dependent myeloma patients. Clin Lymphoma Myeloma Leuk. 2015;15:472-6. doi: 10.1016/j. clml.2015.03.003.

18. Ray SC, Patel B, Irsik DL, Sun J, Ocasio H, Crislip GR, et al. Sodium bicarbonate loading limits tubular cast formation independent of glomerular injury and proteinuria in Dahl salt-sensitive rats. Clin Sci (Lond). 2018;132:1179-97. doi: 10.1042/CS20171630.

19. Ying WZ, Sanders PW. Dietary salt regulates expression of Tamm-Horsfall glycoprotein in rats. Kidney Int. 1998;54:1150-6. doi: 10.1046/j.1523-1755.1998.00117.x.

20. Shawkat H, Westwood M-M, Mortimer A. Mannitol: a review of its clinical uses. Continuing Education in Anaesthesia, Critical Care \& Pain. 2012;12(2):82-5. doi:10.1093/bjaceaccp/mkr063

21. Bragadottir G, Redfors B, Ricksten SE. Mannitol increases renal blood flow and maintains filtration fraction and oxygenation in postoperative acute kidney injury: a prospective interventional study. Crit Care. 2012;16:R159. doi:10.1186/cc11480. doi: 10.1186/cc11480.

22. Schetz M. Should we use diuretics in acute renal failure? Best Pract Res Clin Anaesthesiol. 2004;18:75-89. doi: 10.1016/j. bpa.2003.09.003.

23. MacLennan IC, Cooper EH, Chapman CE, Kelly KA, Crockson RA. Renal failure in myelomatosis. Eur J Haematol Suppl. 1989;51:60-5. doi: 10.1111/j.1600-0609.1989. tb01494.x.

24. Ecotière L, Thierry A, Debiais-Delpech C, Chevret S, Javaugue V, Desport E, et al. Prognostic value of kidney biopsy in myeloma cast nephropathy: a retrospective study of 70 patients. Nephrol Dial Transpl. 2016;31:64-72. doi: $10.1093 / \mathrm{ndt} / \mathrm{gfv} 283$.

25. Hutchison CA, Harding S, Mead G, Goehl H, Storr M, Bradwell A, et al. Serum free-light chain removal by high cutoff hemodialysis: optimizing removal and supportive care. Artif Organs. 2008;32:910-7. doi: 10.1111/j.15251594.2008.00653.x.

26. Bridoux F, Carron PL, Pegourie B, Alamartine E, AugeulMeunier K, Karras A, et al. Effect of high-cutoff hemodialysis vs conventional hemodialysis on hemodialysis independence among patients with myeloma cast nephropathy: a randomized clinical trial. JAMA. 2017;318:2099-110. doi: 10.1001/jama.2017.17924.

27. Dimopoulos MA, Terpos E, Chanan-Khan A, Leung N, Ludwig $\mathrm{H}$, Jagannath $\mathrm{S}$, et al. Renal impairment in patients with multiple myeloma: a consensus statement on behalf of the International Myeloma Working Group. J Clin Oncol. 2010;28:4976-84.

28. Dimopoulos MA, Roussou M, Gavriatopoulou M, Psimenou E, Eleutherakis-Papaiakovou E, Migkou M. et al. Bortezomib-based triplets are associated with a high probability of dialysis independence and rapid renal recovery in newly diagnosed myeloma patients with severe renal failure or those requiring dialysis. Am J Hematol. 2016;91:499-502. doi: 10.1200/JCO.2010.30.8791.

29. Clark WF, Stewart AK, Rock GA, Clark WF, Stewart AK, Rock GA, et al. Plasma exchange when myeloma presents as acute renal failure: a randomized, controlled trial. Ann Intern Med. 2005;143:777-84. doi: 10.7326/0003-4819-14311-200512060-00005.

Copyright $\odot 2021$ The Author(s); Published by Published by Society of Diabetic Nephropathy Prevention. This is an open-access article distributed under the terms of the Creative Commons Attribution License (http://creativecommons.org/licenses/by/4.0), which permits unrestricted use, distribution, and reproduction in any medium, provided the original work is properly cited. 